Relations industrielles

Industrial Relations

\title{
Final Offer Arbitration. A Comment
}

\section{Trefflé Lacombe}

Volume 34, numéro 1, 1979

URI : https://id.erudit.org/iderudit/028944ar

DOI : https://doi.org/10.7202/028944ar

Aller au sommaire du numéro

Éditeur(s)

Département des relations industrielles de l'Université Laval

ISSN

0034-379X (imprimé)

1703-8138 (numérique)

Découvrir la revue

Citer cet article

Lacombe, T. (1979). Final Offer Arbitration. A Comment. Relations industrielles / Industrial Relations, 34(1), 189-194. https://doi.org/10.7202/028944ar

Tous droits réservés @ C Département des relations industrielles de l'Universite Laval, 1979
Ce document est protégé par la loi sur le droit d'auteur. L'utilisation des services d'Érudit (y compris la reproduction) est assujettie à sa politique d'utilisation que vous pouvez consulter en ligne.

https://apropos.erudit.org/fr/usagers/politique-dutilisation/ 


\section{COMMENTAIRE}

\section{FINAL OFFER ARBITRATION - A COMMENT}

\section{TREFFLÉ LACOMBE}

I have read with keen interest the recent articles on Final Offer Arbitration. Although it is too early to draw firm conclusions from the experience of the University of Ottawa, I thought I would share our perception of the usefulness of the technique.

In the fall of 1975 the professors of the University choose to unionize under the Ontario Labour Relation Act. Early in October the negotiations began. The professor's Association (A.P.U.O.) proposed that the parties agree immediately that in the event of a failure of the parties to agree on a financial settlement, the matter be referred to binding arbitration.

Initially the Board of Governors and the administration of the University were very hesitant. They expressed the traditional reservations to a third party settlement. After carefully weighting the pros and cons the University's negotiators were authorized to agree providing three conditions were set:

$1^{\circ}$ we would proceed to arbitration on financial matters providing that all non-monetary matters had been previously resolved,

$2^{\circ}$ that the arbitration be done by a panel of three arbitrators and,

$3^{\circ}$ the arbitration be conducted according to the technique of Final Offer Selection.

The APUO agreed with the conditions and on November 13, 1975, the parties signed a document which reads as follows:

Agreement made at the City of Ottawa in the Regional Municipality of Ottawa-Carleton, this 13th day of November, 1975.

\section{BETWEEN :}

\section{UNIVERSITY OF OTTAWA}

Hereinafter referred to as «University » - PARTY OF THE FIRST -

* LACOMBE, Trefflé, Vice-recteur adjoint, relations du travail, Université d'Ottawa. 
AND

\section{ASSOCIATION OF PROFESSORS OF THE UNIVERSITY OF OTTAWA \\ Hereinafter referred to as «APUO» - PARTY OF THE SECOND PART -}

WHEREAS the Ontario Labour Relations Board has issued a provisional certificate to APUO dated September 10th, 1975;

AND WHEREAS, the APUO and the University desire to enter into meaningful collective bargaining with a view of achieving a collective agreement;

AND WHEREAS, the University and APUO desire to avoid any threat of lockout, strike, work-stoppage or work slow-down on matters relating to salary or fringe benefits;

AND WHEREAS, it is in the best interests of both the University and the APUO that an amicable means of settlement be agreed to in the event that the parties cannot agree by collective bargaining on any item of salary or fringe benefits ;

NOW THESE PRESENTS WITNESSETH that, in consideration of the premises and of the mutual covenants and agreements hereafter, the parties hereto have agreed as follows:

1 - The University and the APUO hereby agree that there shall not be, from the date hereof to such date as a collective agreement is duly and properly executed by both parties, any lockout by the University, or any form of strike, work-stoppage or work slow-down by members of the APUO upon matters dealing with salary or fringe benefits, and the APUO further agrees that it will take all necessary measures, from the date hereof to the date of execution of a collective agreement, to avoid, discourage, repress and oppose a picket line, information line or any other similar manifestation by its members, collectively or individually upon matters dealing with salary or fringe benefits which may or is calculated to cause any disruption of work, services or deliveries to, from or in any sector or area of the University.

2 - The University and APUO hereby mutually agree one with the other, that, in the event that any member of personnel of the University other than a member of the bargaining unit a described in the aforementioned provisional certificate, is in breach of of the provisions of paragraph 1 hereof, the University may take whatever measures or means are available in law, including disciplinary measures, to insure compliance with paragraph 1 hereof; in the event that any member of APUO is in breach of paragraph 1, then APUO will take all reasonable means or measures to insure compliance with paragraph 1 hereof by such member or members. 
3 - In the event after negotiating in good faith the parties are unable to agree upon matters dealing with salary or fringe benefits, and providing that all other matters have been either agreed to be set aside or resolved and mutually agreeable provisions for inclusion in a collective agreement have been executed by both parties, then either party can serve upon the other party a notice of arbitration in writing, such notice to contain the following:

(a) a statement of all the matters in issue which is to be submitted to arbitration together with the final offer of that party for settlement of the issue;

(b) the name of the party's nominee to act as arbitrator.

4 - Within five (5) working days of the receipt of the notice of arbitration mentioned in paragraph 3 hereof, the other party shall serve a reply to contain the following:

(a) a statement of any disagreement as to the matter in issue contained in the notice of arbitration together with that party's final offer for the settlement of the issue;

(b) the name of the nominee as arbitrator of such other party.

5 - Within five (5) working days of the service of the reply provided for in paragraph 4 hereof, the nominees of both parties shall meet and select by mutual consent a third arbitrator from a previously agreed upon list of three (3) to act as chairman. In the event that the nominees of both parties are unable to agree upon a chairman, they shall select one (1) from the above-mentioned list by lot.

6 - The arbitrators shall not be members of the APUO nor any other employee of the University of Ottawa or a member of its Board of Governors.

7 - The arbitrators shall have jurisdiction to decide as between the final offers of settlement submitted by the parties for (one) salaries and/or for (two) fringe benefits pursuant to paragraphs 3 and 4 hereof and shall not have jurisdiction to decide upon any other matter or in any way to alter, modify, amend or change the final offers of settlement submitted by the parties.

8 - The decision of any two arbitrators shall be binding and final upon both parties and in the event that two arbitrators cannot agree then the decision of the chairman shall bind both parties. The arbitrators shall render their decision within twenty (20) working days of the appointment of the chairman, unless such time is mutually extended by both parties.

9 - This present agreement shall constitute a submission within the meaning of the Arbitration Act, being R.S.O. 1970, Chapter 25 and amendments and is made pursuant to section $34 \mathrm{c}$ of the Ontario Labour Relations Act R.S.O. 1979, ch. 232 as amended. 
10 - Each party shall bear the cost of its arbitrator and any witness produced by such party, and the expenses of the chairman shall be borne equally by both parties.

11 - This present agreement shall not for any purpose be deemed or considered as a collective agreement between the parties hereto.

12 - For the purposes of this agreement, «fringe benefits» are those referred to in University of Ottawa policies 7, 8, 13, 22 and 46 in force on this date, and any additional matters agreed to by mutual consent.

IN WITNESS WHEREOF both parties have caused these presents to be executed by their duly authorized representatives.

\title{
UNIVERSITY OF OTTAWA per:
}

\section{ASSOCIATION OF PROFESSORS OF THE UNIVERSITY OF OTTAWA per:}

The parties agree that the following persons may serve as chairman of the arbitration board referred to in the agreement of Nov. 13th, 1975.

\author{
Mr. H. C. Goldenberg \\ Mr. Innis Christie \\ Mr. P. C. Weiler
}

The parties then proceeded to negotiate the first collective agreement. After several months we reached the financial questions and eventually the parties referred the matter to arbitration as prescribed by the agreement of November 1975. Mr. Innis Christie, chairman of the Nova Scotia Labour Board chaired the arbitration panel.

What follows is the point of view of one who actively participated in the process as a representative of management.

The University's negotiating team was authorized by the Board of Governors to submit what we all deemed to be a very reasonable offer.

Throughout our planning we were guided by 1) the availability of our resources 2) our competitive position in our labour market (similar Ontario Universities) 3) our knowledge of the offers made by sister institutions (non-unionized) 4) the current economic situation and 5) trends in settlements among bargaining units. The existence of the antiinflation board did not play a major role in our deliberations. We were aware, of course, that our settlement would need to be eventually approved by the A.I.B.

It is my assessment that the recourse to Final Offer Selection arbitration brought about precisely what the theoreticians claim it should. Both parties made every effort to be very reasonable in order to convince 
the arbitrators of the merit of their case. In fact, only $2 \%$ separated the parties in their respective final positions.

The arbitrators found in favor of the final position of the faculty Association. Eventually the settlement was rolled back by the A.I.B. to a position almost identical to the management final position.

The Association proposed that the agreement of November 1975 apply to the wage reopener provided for in the two year collective agreement, and the University agreed. During the wage negotiations of 1977, it was also agreed by the parties that if a financial dispute would occur during the 1978 negotiations, it would also be resolved under the aegis of the 1975 agreement.

Both the 1977 wage reopener and the negotiations of 1978 were resolved by agreement of the parties at the bargaining table. I will now examine whether the possible use of Final Offer Selection arbitration had any impact on the parties.

During the negotiations of 1977 , the existence of the Anti-Inflation Board played an important role. The 1976 decision of the Arbitrators had been rolled back. By then both parties could reasonably assess what the Board would accept and what it would roll back. Neither party was interested in unduly delaying a settlement. Consequently, after two bargaining sessions, it became evident that the parties would reach an agreement slightly under the A.I.B. guidelines.

One could, therefore, say that the ultimate recourse to Final Offer Selection arbitration had no noticeable effect on the management position. One might suggest that the fear of the pendulum effect may have influenced the APUO. I do not believe it had much impact in 1976. The bargaining positions of the parties were close enough and the existence of the A.I.B. was the overriding factor.

The situation changed radically in 1978. The contract year being May 1st to April 30, the negotiations were conducted outside of the A.I.B. regulations. This time the possible referral to arbitration played a very significant role in the negotiations.

After several months of bargaining we eventually reached the monetary issues. The starting positions were far enough. However, the Association moved quickly to narrow the gap. The initial management position was much influenced by what was happening at other universities in Ontario and our policy of reasonableness.

After a few sessions, it was evident that we may have to refer the matter to arbitration. At that point the only element still in question was the economic increase. The Union was requesting $7 \%$ and management was offering $5 \%$. The management team had been reassessing its position constantly in light of developments at other universities. By then it was evident that a settlement, even at a $5 \%$ economic increase would far exceed decisions rendered in the non-unionized universities. The bargaining team was now under a lot of pressure to bring the settlement down. 
There is no doubt that at that point we began to measure the possible outcomes of going to arbitration. We tried to measure how much we would have to offer to anyone of the three possible chief arbitrators in order to win approval for our final offer. It is difficult of course to be very scientific, but one can read decisions rendered in other cases by the same arbitrators and one knows the reputation of these arbitrators. We are convinced that the Union was doing exactly the same exercise because at the next bargaining session the Union moved to a $6.5 \%$ position, explaining that they thought that with such a reasonable position they could win an arbitration award from two of the three possible arbitrators. This corresponded to the management team's assessment. It was felt that one of the possible arbitrators could perhaps find in favor of a position slightly below a $6 \%$ economic increase.

The University's representatives put forth a proposal of $5.5 \%$ and tried to convince the Union that it was very reasonable, much above what other university professors in Ontario would receive.

We tried to convince the Union that it would be much better for both parties to reach a settlement at the table, that we should measure the saving of not going to arbitration and consequently, the Union should take this into account in determining its final position.

The management team choose to consult its principles before proceeding any further. We informed the Board of the state of the negotiations. We also informed the Board of our evaluation of the possible outcomes of arbitration. What the University had to assess was whether we should gamble on the selection of one of three arbitrators, or whether we could reach an agreement with the Union by offering an increase that the Union would deem almost as good as a possible outcome of arbitration. After discussion it was agreed that the University could offer as much as $6 \%$ but no more. If this was refused, we would take our chances at arbitration.

At the next bargaining session, the University eventually offered the $6 \%$ which after caucus, deliberations and consultation was accepted by the APUO.

There is no doubt that the final outcome of these negotiations was very much influenced by the possible recourse to arbitration. I am convinced that the University made every possible effort to be reasonable and to be judged by an arbitrator if we would have had to proceed to arbitration under the technique of Final Offer Selection.

The parties signed a three year collective agreement with a wage reopener after the first and after the second year of the contract. We further agreed that a failure to reach agreement at the bargaining table would imply a recourse to our agreement of November 1975 thereby referring our disagreement to binding arbitration by Final Offer Selection.

By the summer of 1980 our experience may be more telling. 